\title{
Lasiotocus lizae sp. n. (Digenea: Monorchiidae), a new trematode from marine fish in the Taiwan Straits, China
}

\author{
Liu Sheng-fa \\ Parasitology Research Laboratory, School of Life Sciences, Xiamen University, Xiamen, 361005, China
}

Key words: Digenea, Lasiotocus, Liza carinata, Taiwan Straits

\begin{abstract}
Lasiotocus lizae sp. n. (Digenea: Monorchiidae) was collected from the intestine of Liza carinata (Valenciennes) (Mugilidae, Perciformes) in the Taiwan Straits, China. L. lizae is most similar to Lasiotocus glebulentus Overstreet, 1971 from the intestine of Mugil cephalus from the Northern Gulf of Mexico in having tightly compacted vitellaria, a genital pore sinistral to the midline, the ovary usually dextral to the acetabulum, the similar sucker ratio, and in the presence of both a canalicular and uterine seminal receptacle. It differs from L. glebulentus in its cirrus sac ending anterior to rather than posterior to acetabulum, in the ending position of caeca, in smaller eggs, and in having a single rather than several conspicuous concretions in excretory vesicle.
\end{abstract}

The Monorchiidae is a large trematode family and consists of more than 120 described species belonging to about 50 genera. Approximately 20 species have been described from marine fishes in China (Shen 1994, Zhang et al. 1999). During the survey of digenetic trematodes of marine fishes in the Taiwan Straits, China, between September 1999 and June 2001, an undescribed species of monorchiid trematode was discovered from the intestine of the marine fish, Liza carinata (Valenciennes). It is described as a new species below.

\section{MATERIALS AND METHODS}

Freshly caught Liza carinata from the coast of Xiamen ( $\left.24^{\circ} 29^{\prime} \mathrm{N}, 118^{\circ} 04^{\prime} \mathrm{E}\right)$, Fujian Province, People's Republic of China were examined for helminths. All helminths were recovered alive, fixed under a cover glass in $10 \%$ formalin solution at room temperature, stained in Grenacher's alcoholborax carmine, dehydrated, cleared in clove oil, and mounted in Canada balsam. The figures were drawn with the aid of a drawing apparatus. Measurements are given in millimetres, as the range followed by the mean in parentheses, unless otherwise stated. "Sucker ratio" refers to the ratio of the sum of length and width of the oral sucker to that of the acetabulum.

\section{RESULTS}

\section{Lasiotocus lizae sp. n.}

Figs. 1-4

Description (based on 13 specimens): Body oval, tapers at extremities, $0.528-0.732 \times 0.248-0.304(0.610$ $\times 0.275)$, width $37-58 \%(46 \%)$ of length. Tegument entirely spined, but tegumental spines sparse posterior to acetabular level. Forebody 0.036-0.056 (0.047) long, $28-33 \%(31 \%)$ of body length. Oral sucker nearly round, subterminal, 0.056-0.074 × 0.070-0.094 (0.064 ×
0.078). Acetabulum round, 0.074-0.084 × 0.082-0.094 $(0.079 \times 0.088)$. Sucker ratio $1: 1.09-1.25$ ( $1: 1.18)$. Prepharynx very short. Pharynx globular, 0.022-0.038 $\times$ 0.032-0.040 $(0.030 \times 0.036)$. Oesophagus short, 0.0160.036 (0.024) long, bifurcating in middle of forebody. Caeca terminating slightly posterior to or at level of acetabulum.

Testis single, smooth, oblong to oval, $0.110-0.210 \times$ $0.092-0.148(0.167 \times 0.115)$, postequatorial. Posttesticular space $0.106-0.244$ (0.173), 17-38\% (28\%) of body length. Cirrus sac thick-walled, 0.100-0.166 $\times$ 0.034-0.048 $(0.135 \times 0.040)$, preacetabular, sinistral to midline, preacetabular, containing seminal vesicle, pars prostatica, cirrus, and prostatic cells. Seminal vesicle sac-like, $0.038-0.072 \times 0.026-0.046(0.057 \times 0.036)$. Pars prostatica short, narrow, tubular, 0.010-0.020 (0.016) long. Cirrus 0.044-0.090 (0.069) long, armed with spines. Genital atrium shallow, unspined. Genital pore opening near left margin of body between caecal bifurcation and acetabulum.

Ovary tri-lobed, nearly equatorial, usually dextral, $0.108-0.158 \times 0.048-0.080(0.134 \times 0.063)$. Seminal receptacle small, spherical or ovoid, 0.016-0.028 $\times$ 0.008-0.012 $(0.021 \times 0.010)$. Laurer's canal straight, directed posteriorly, $0.106-0.172(0.130)$ long. Uterine seminal receptacle present, conspicuous. Vitellaria consisting of two ovoid, compact masses, each measuring 0.048-0.108 $\times 0.032-0.070(0.080 \times 0.050)$, situated at acetabular level or immediately posterior to acetabulum. Uterus occupying hindbody, and entering terminal organ near middle of it. Terminal organ bipartite, $0.038-0.052 \times 0.020-0.032(0.045 \times 0.024)$; proximal half unspined, distal half armed with slender spines. Eggs oval, operculate, 0.018-0.022 × 0.008$0.010(0.019 \times 0.009)(45$ eggs measured $)$, and containing well-developed miracidia. 


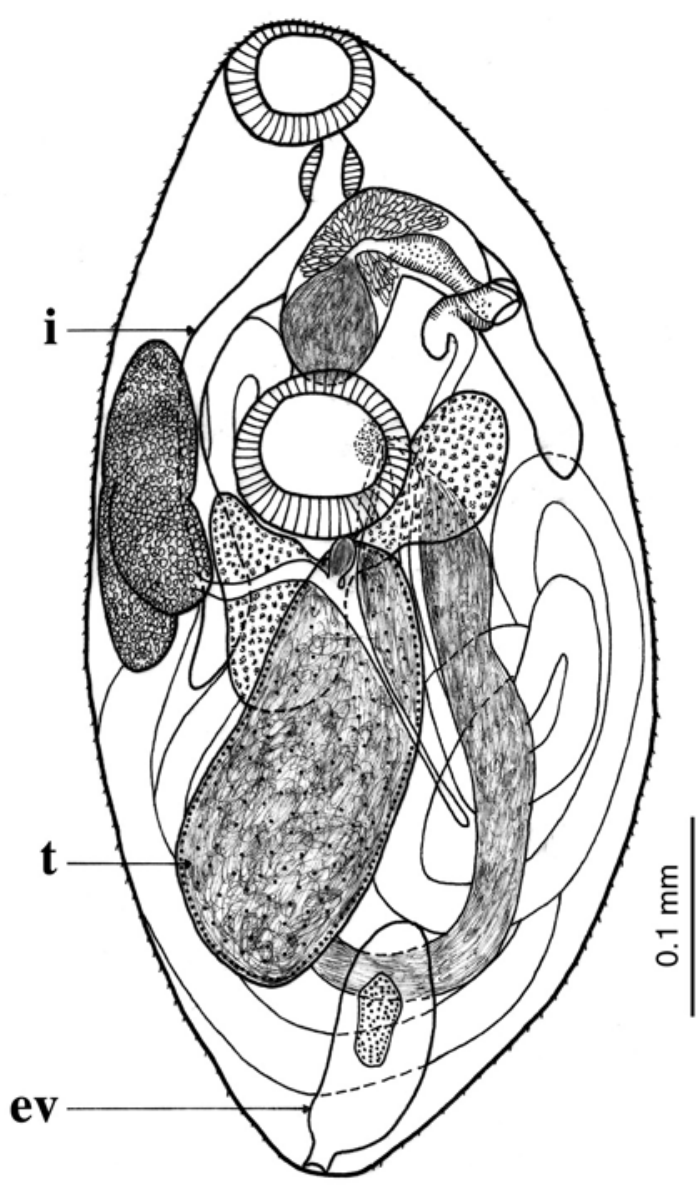

1

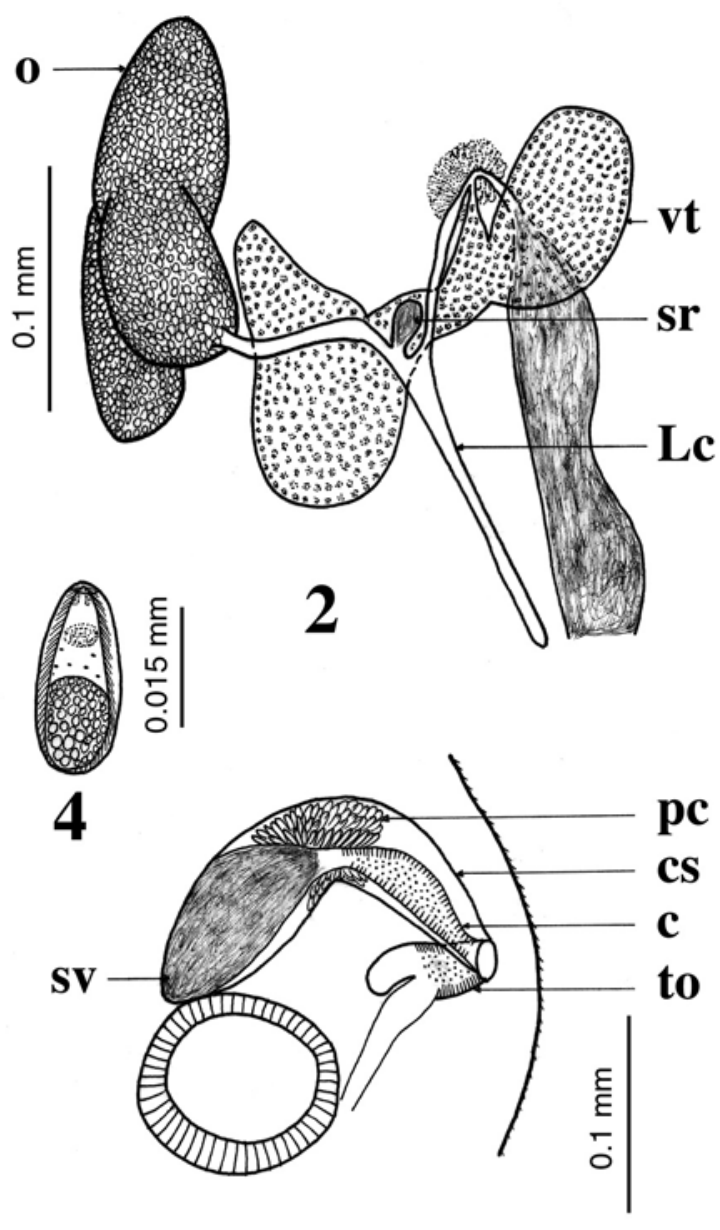

3

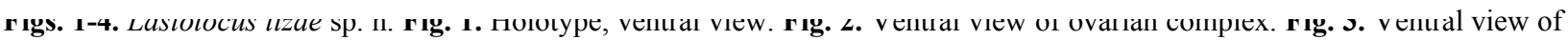
terminal genitalia. Fig. 4. Egg. Abbreviations: c - cirrus; cs - cirrus sac; ev - excretory vesicle; i - intestine; Lc - Laurer's canal; $\mathrm{o}$ - ovary; $\mathrm{pc}$ - prostatic cell; $\mathrm{sr}$ - seminal receptacle; $\mathrm{sv}$ - seminal vesicle; $\mathrm{t}$ - testis; $\mathrm{vt}$ - vitellarium; to - terminal organ.

Excretory vesicle saccular, sometimes containing an irregular concretion. Excretory pore terminal.

$\mathrm{T}$ y p e h o s t : Liza carinata (Valenciennes) (Mugilidae, Perciformes).

Site of infection: Intestine.

T y p e 1 o c a 1 it y : Xiamen $\left(24^{\circ} 29^{\prime} \mathrm{N}, 118^{\circ} 04^{\prime} \mathrm{E}\right)$, Fujian Province, China.

Prevalence and intensity of infection: $14.9 \%$ (41 fishes infected / 275 examined), 1-306 (24) worms per fish.

$\mathrm{S} p$ e c i m e n s d e p o s i t e d : Holotype No. fjxm20010208-1 and paratypes Nos. fjxm20010208-2-13 are deposited in Parasitology Research Laboratory, Xiamen University, People's Republic of China. Four paratypes No. D-464 are deposited in the helminthological collection of the Institute of Parasitology, Academy of Sciences of the Czech Republic, in České Budějovice.

E t y m o 1 o g y: The species name refers to the type host, Liza carinata.

\section{DISCUSSION}

More than 37 species of Lasiotocus have been described to date (Overstreet 1971, Yamaguti 1971, Fischthal and Nasir 1974). The new species is most similar to Lasiotocus glebulentus Overstreet, 1971 from the intestine of Mugil cephalus (Linnaeus) (Mugilidae, Perciformes) from the Northern Gulf of Mexico in having tightly compacted vitellaria, a genital pore sinistral to the midline, the ovary usually dextral to the acetabulum, the similar sucker ratio, and in the presence of both a canalicular and an uterine seminal receptacle [Overstreet (1971) did not describe the uterine seminal receptacle in the text, but the structure can be found in his fig. 15]. It differs from L. glebulentus in its cirrus sac ending anterior to rather than posterior to acetabulum, in the ending position of caeca (caeca terminating anterior to or at middle level of testis in L. lizae but at or posterior to testicular level in L. glebulentus), in smaller 
eggs $(0.018-0.022 \times 0.008-0.010$ in $L$. lizae versus $0.021-0.030 \times 0.009-0.013$ in L. glebulentus), and in having a single rather than several conspicuous concretions in excretory vesicle and a shorter prepharynx.

Other species with a submedial genital pore in the genus Lasiotocus are L. odhneri (Srivastava, 1939) Thomas, 1959, L. minutus (Manter, 1931) Thomas, 1959, L. elongatus (Manter, 1931) Thomas, 1959 and $L$. mugilis Overstreet, 1969, but they have separate vitelline follicles and no excretory concretion. In addition, $L$. odhneri has a smaller sucker ratio ( $1: 0.7)$ and larger body (2.0-2.4 $\times 0.58), L$. minutus has the oral sucker larger than the acetabulum and smaller eggs $(0.016-0.017 \times 0.007-0.008)$ and in L. minutus the caeca consistently end near the end of body, and the eggs are smaller (0.011-0.017 × 0.009-0.010).

Acknowledgements. This study was supported by the National Natural Science Fund of China, grant No. 39870144, and the Natural Science Fund of Fujian Province, China, grant No. B0010002.

\section{REFERENCES}

FISCHTHAL J.H., NASIR P. 1974: Some digenetic trematodes from freshwater and marine fishes of Venezuela. Norw. J. Zool. 22: 71-80.

OVERSTREET R.M. 1971: Some adult digenetic trematodes in striped mullet from the Northern Gulf of Mexico. J. Parasitol. 57: 967-974.

SHEN J.W. 1994: Trematoda. In: Z.G. Huang (Ed.), Marine Species and Their Distributions in China's Seas. China Ocean Press, Beijing, pp. 306-325. (In Chinese.)

Received 8 October 2001
YAMAGUTI S. 1971: Synopsis of Digenetic Trematodes of Vertebrates. Vols. 1-2. Keigaku Publ. Co., Tokyo, 1,074 pp.

ZHANG J.Y., QIU Z.Z., DING X.J. 1999: Parasites and Parasitic Diseases of Fishes. Science Press, Beijing, China, 735 pp. (In Chinese.)

Accepted 28 January 2002 